\section{Protein crystals go bang}

SIR - Daedalus ${ }^{1}$ indicates the destructive potential contained in the crystal lattice of antimony and the plans of DREADCO's chemists to produce explosive, yet stable, forms of crystals modified by proteins. But he may be interested to hear that crystallographers have already observed in pure protein crystals some ability to undergo this violent self-destruction.

Like the explosive form of antimony, a slight mechanical impact with a needle often results in rapid shattering and destruction of these protein samples. The small size of protein crystals normally available for X-ray analysis (about $0.1-1 \mathrm{~mm}^{3}$ ) may have saved many unwary scientists from serious injury! This type of detonation can also be catalysed by heavy metals. Combining $5 \mathrm{mM}$ $\mathrm{Hg}\left(\mathrm{NO}_{3}\right)_{2}$ with crystals of the avian pancreatic polypeptide, for example, results in an impressive and rapid disintegration $^{2,3}$.

The development of proteins engineered for a highly explosive transition of crystal habit could be attempted by recombinant DNA techniques and sitedirected mutagenesis. Engineered surface loops trapped in a crystal lattice but highly mobile in the non-crystalline state are likely to act as triggers for rapid ignition. Much like the development of gas centrifugation used previously to purify uranium, massive crystallization centrifuges would have to be constructed to produce the extremely large protein crystals required to reach a critical mass ${ }^{4}$. Even the technology for producing a self-destroying 'plastic explosive' bag suggested by Daedalus is available using protein crosslinking agents like glutaldehyde. This exciting prospect opens up a whole new avenue for generous research funding on the development of peaceful uses for this terrifyingly destructive material.

\section{Jim E. Pitts}

Department of Crystallography.

Birkbeck College,

University of London,

Malet Street, London WC1E 7HX, UK

1. Jones, D. Nature 358, 546 (1992).

2. Pitts, J. E. thesis (Univ. Sussex, 1980).

3. Blundell, T. L., Pitts. J. E., Tickle, I. J., Wood, S. P. \&

Wu, W.-C. Proc. natn. Acad. Sci. U.S.A. 78, 4175-4179 (1981).

4. Pitts, J. E. Nature 355, 117 (1992)

\title{
Chemical evidence for ancient beer
}

SIR - Lower Mesopotamia, comprising the wide alluvial plain of the lower Tigris and Euphrates rivers, was home to one of the oldest literate civilizations in the world - that of the early Sumerian city-states - dating back to the Late Uruk Period (late fourth millennium $\mathrm{BC})^{1}$. Irrigation agriculture of domesticated cereals included barley, from which beer is made. Beer was the preferred fermented beverage of the ancient Sumerians ${ }^{2}$. Godin Tepe, a site (excavated by a team from the Royal Ontario Museum) in the nearby Zagros mountains of Iran which has strong Lower Mesopotamian influences, has yielded the earliest chemical evidence for beer. We have discovered a characteristic organic residue inside a pottery vessel which was evidently used for beer fermentation or storage.

During the late fourth millennium $\mathrm{BC}$, the early Sumerians exploited surrounding areas for precious commodities ${ }^{3}$. At Godin Tepe, the discovery of various artefacts in well-constructed buildings contemporary with the Late Uruk lowland city-states ${ }^{4}$ indicates the presence of early Sumerians (V.R.B., manuscript in preparation).

The people at Godin Tepe, with their close ties to lowland Mesopotamia, were probably also beer drinkers. Carbonized six-row barley was very common at the site $^{5}$ and could have been converted to beer there. We have observed curious criss-cross grooves covering the interior below the shoulder of a Late Uruk jar from Godin Tepe (see figure). If the jar served as a beer vessel, the grooves may have been designed to retain beer sediments. The early Sumarian sign for beer (kaš; ref. 6) shows a jar with similar linear markings (see figure). Together,

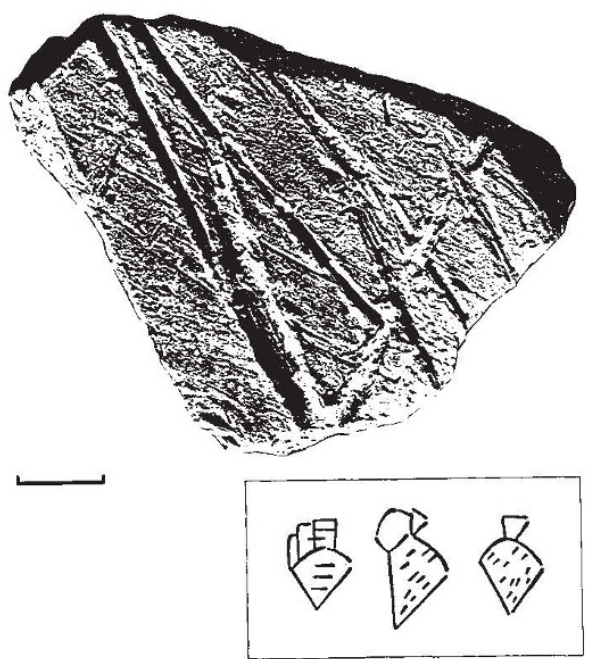

Comparison of interior of beer jar from Godin Tepe (Royal Ontario Museum) (top) and Sumerian graphic signs for beer (kaš) with respective grooves and internal markings. Scale bar, $1 \mathrm{~cm}$. (Photo courtesy of W. Pratt, Royal Ontario Museum.) the archaeological and textual evidence strongly suggest that this vessel was a beer container.

Some of the grooves contained a pale yellowish residue which gave a positive test $^{7}$ for oxalate ion. Calcium oxalate, which is soluble in water only with difficulty $\left(6 \mathrm{mg} \mathrm{l}^{-1}\right.$ at $\left.18{ }^{\circ} \mathrm{C}\right)$, is a principal component of 'beerstone' and settles out on the surfaces of fermentation and storage tanks of barley beer ${ }^{8}$. Similar test results were obtained from scrapings from an Egyptian New Kingdom jar (clearly intended for beer according to tomb paintings and reliefs), beerstone from a modern brewer's vat, and pure calcium oxalate.

Spinach and rhubarb, which grow in the Iranian highlands today and presumably grew there in the past, contain substantial amounts of oxalates $(5-10 \%)$. Compared to cereals, however, they are a minor part of the human diet and we can think of no reason why they should have been stored or processed in the ancient grooved vessel. Although minor amounts of oxalates are widely distributed in nature, exterior scrapings of our Uruk jar and the interiors of vessels from the same site which originally contained a grape product all gave negative results.

The chemical evidence for the earliest beer at Godin Tepe complements the finding of the earliest grape wine there, also dating to the last half of the fourth millennium $\mathrm{BC}^{9}$. Analysis of storage and processing containers from earlier periods and from a wider geographical area are needed to determine the ultimate origins and significance of beer production.

\section{Rudolph H. Michel}

Patrick E. McGovern

Museum Applied Science Center for Archaeology (MASCA),

University Museum of Archaeology and Anthropology,

University of Pennsylvania,

Philadelphia,

Pennsylvania 19104, USA

Virginia R. Badler

Department of Near Eastern Studies,

University of Toronto,

Toronto, Ontario,

Canada M5S $1 A 1$

1. Nissen, H. J. The Early History of the Ancient Near East, 9000-2000 B.C. (University of Chicago, 1988).

2. Röllig, W. Das Bier im alten Mesopotamien

(Gessellschaft für die Geschichte und Bibliographie des Brauwesens, Berlin, 1970)

3. Algaze, G. Curr. Anthrop. 30, 571-608 (1989); 31 66-69 (1990).

4. Weiss, H. \& Young, T. C. Jr Iran 13, 1-17 (1975).

5. Miller, N. F. in Progress in Old World Palaeoethnobotany (eds Van Zeist, W., Wasylikow, K. \& Behre, E.-E.) 133-160 (Balkema, Rotterdam, 1991)

6. Green, M. W. \& Nissen, H. J. Zeichenliste der archäischen Texte aus Uruk (Mann, Berlin, 1987).

7. Feigl, F. Spot Tests in Organic Applications (Elsevier, New York, 1954).

8. DeClerck, J. A Textbook of Brewing (translator BartonWright, K.) (Chapman and Hall, London, 1957).

9. Badler, V. R., McGovern, P. E. \& Michel, R. H. in MASCA Res. Pap. Sci. Archaeol. 7, 25-36 (1990). 